\title{
Effect of Amla Sheet dravya (Amalaki) in Anemic Patients with Reference to Amla Sheet Prathana
}

\author{
${ }^{1}$ Vyas Suwarna D., ${ }^{2}$ Vyas Deepak M. , ${ }^{3}$ Topare Sunil G ${ }^{4}$ Thakare Prabhakar B \\ ${ }^{1}$ (Kriya Sharir) Assistant Professor, Govt. Ayurved College, Nagpur \\ ${ }^{2}$ (Kriya Sharir) Associate Professor, Jupiter Ayurved Medical College, Nagpur \\ ${ }^{3}$ (Kriya Sharir) Associate Professor, Govt. Ayurved College, Nagpur \\ ${ }^{4}$ (Kriya Sharir) Associate Professor, Govt. Ayurved College, Mumbai
}

\section{Corresponding Author : Dr, Deepak M Vyas}

201 Arihant Apartment, Behind Akash Mall, Ayachit Mandir Road, Mahal, Nagpur. 440032.

\begin{abstract}
Ayurveda is an ancient science life. It is observed that according to various seasons our Aahara and Vihara undergo a change. In the early stage, to maintain homeostasis body tries to compensate this stage by demanding a particular food and drink of specific Rasa, Guna, Virya and Vipaka. Rakta is one of the most important Dhatu of our body. When Rakta Dhatu, gets deminute in the body initially body tries to compensate this condition by showing Amla sheet Prarthana. In the Sushrut Samhita, it was quoted that in kshaya stage body demands for particular type of food if we fulfill that demand then the Dhatu comes in normal state. So the aim of this paper is to study effect of Amla Sheet dravya (Amalaki) in Anaemic Patients with reference to Amla Sheet Prathana. This is clinical study carried out on 30 anemic patients attending OPD and IPD of Government Ayurved College hospital Nagpur.. In this study there was two group having 15 patients in each group. In Group A Amla, sheet Dravya Aamalki was given to the patients of Rakta kshaya having Amla - Sheet Prarthana. Statistical analysis with the help of student's paired' $t$ ' test shows there is significant changes were seen in Amla - Sheet Prarthana, Hemoglobin percentage $(\mathrm{P}<0.05$ i.e.0.023) and Red cell count ( $\mathrm{P}<0.05$ i.e. 0.015).In group $\mathrm{B}$ patients of Rakta kshaya was on routine normal diet. It was observed that Amla Prarthana was significantly reduced but changes observed in sheet Prarthana was insignificant. There is an insignificant changes observed in Hemoglobin percentage ( $p>0.05$ i.e. 0.57) and RBC (P > 0.05 i.e. 0.35).It is concluded that Amla Sheet Dravya Amalaki has significant effect to reduce Amla Sheet Prathana and to increase Hemoglobin, RBC count.
\end{abstract}

Key Words- Rakta Dhatu, Amla Sheet, Amalaki Craving, LAM Scale,

\section{INTRODUCTION}

Dosha - Dhatu - Mala these three entities governs the life process of body. Every second in body, so many metabolic processes going on by which new cells formed and older cells become dead. Metabolism involves both catabolism and anabolism. Catabolism can be understood by definition of Deha and anabolism can be understood by definition of Sharir. Various changes occur due to metabolism at the level of Dosha-Dhatu - Mala. Today it is observed that when there is a change in the season, humans change their dietary pattern and lifestyle. Nature also binds them to change their lifestyle. It is also observed that in Visarga kala our Jatharagni increase and in Adana kala, Jatharagni decrease1. Initially body tries to compensate these changes, in some disorder also. The Body's compensatory mechanism act up to certain limit, after that decompensatory stage starts .In de-compensatory stage special intervention is needed to correct it.

Dosha Dhatu and Mala are root cause of Shareer (1). out of all Dhatus Rakta Dhatu is very important because it is responsible for life and nourishes the Shareer (2).Rakta Dhatu is important one as Raktam Jiva Iti Stitit (3)i. Rakta is a main cause for Utapatti,Stiti and Nasha of the Sharir as that of Tridosha (4).The 


\section{Vyas Deepak M. , International Journal of Ayurvedic \& Herbal Medicine 8(3) May.-June. 2018 (3245-3252)}

main function of Rakta Dhatu is Varnaprasadhana and Mamsapushti. (5).The main sites of Rakta Dhatu utpatti are Yakrit and Pleeha . (6)When Rakta Dhatu diminishes it cause Rakta Dhatu Kshaya (anemia).In this condition initially body tries to compensate the condition by showing craving for Amlasheet rasa. (7) (8) (9).Best example for this concept is that in Garbhiniavasta Garbhini demand for Amla Rasa in second trimester due to Raktalpata (anaemia). In Sushruta Samhita it was quoted that in Kshaya Avasta body demands for particular type of food if we fulfilled that demand then dhatu comes in normal stage. Up to certain extent Rakta kshaya can be correlated with anemia. Few Ayurvedic experts correlate anemia with $P a n d u$. In medical science literature, it was found that there is craving for ice, chips and lettuce in iron deficiency anemia.in survey study it was concluded that Amla sheet Prathana was present in most of anaemic patients. (10) Therefore; the aim is to study the effect of Amlasheet Dravya (Amalaki) in patients suffering from Rakta kshaya

\section{Aim}

To study the effect of Amlasheet Dravya (Amalaki) in patients suffering from Rakta kshaya

\section{LITERATURE REVIEW}

Rakta is vital Dhatu of our body. It is mentioned in Dasa Pranayatana to show its importance. It is well known by the word Jiva, Oja. It's kshaya or diminutation is detrimental to human being. The Rakta is acceptable to be the cause of survival. It is consider being the cause of origin, maintenance and destruction of body. Acharya Chakrapani in the Bhanumati commentary specifies that the Rakta is the cause of its successive Dhatu Mamsa and is the cause of survival. In the formation of Rakta Dhatu following factors are important - Rasa Dhatu, Raktagni, Ranjaka Pitta, Raktavaha Strotasa, Yakrit, Pleeha.

Rakta Dhatu is formed from previous Rasa. The Rasa is precursor for all Dhatu. The next immediate Dhatu, which is to be nourished by Rasa, is Rakta Dhatu. All hypothesis of Dhatu Poshana have accepted the fact that the Rasa is the cause of Rakta. Acharya Chakrapani clearly mentioned the role of Rasa in nourishment of Rakta Dhatu in context of Pandu. He commented that Rakta kshaya is due to diminution of Rasa Dhatu by increased Pitta or failure of Rasa Dhatu to produce the Rakta Poshaka part

\section{Factors responsible for Rakta kshaya:-}

Ativvriddhi of Dhatwagni-Dhatwagni is one of the important factors in Dhatu kshaya Vriddhi. It is the portion of kayagni, which reside in Dhatu. The increase or decrease in Dhatwagni produces decrease or increase Dhatu respectively. Strotorodh is one of the factors responsible for kshaya. The Strotas are the channel, which carries the nutrients material to the required Dhatu. It is the place of transformation and transportation of Dhatu. The partial or complete obstruction in Strotas leads to inadequate or non-supply of Rakta Poshakamsha and resulting in Rakta kshaya. Similarly, in obstruction of Rasavaha Strotas will affect on nourishment of successive Dhatu and leading to Rakta kshaya. Atirakta strava is one of important causative factor in Rakta kshaya. This cause is clearly mentioned by Acharya Susruta and other. They quoted the causes behind Atirakta strava like excessive flow in case of any type of bloodletting procedure or due to faulty Shalya karma.Marmaghat means Injury to certain Marma (vital part) like Indravasti, Urvi, Lohitaksha, and Sira Marma lead to Rakta kshaya immediately without diminuting other Dhatu. Other factore responsible for kshaya are physical exercise, fasting, anxiety, Intake of ununscious food and drink, food in less quantity or habitual intake of food having one taste only, exposure to wind and sun, grief, vigil, excessive elimination of plegum, blood, semen and other excreta, old age and Adana Kala and demoniac seizures'. In Garbhavastha, both mother and Garbha got Jivana from mothers Rakta. After Garbha Hridaya vyakti, the Garbha Sharir requires more Dhatu Poshana for its growth and development. So in the condition there is diminutation of all Dhatus specially Rakta in the mothers as compare to demand. In this case, there is also a situation of Rakta kshaya.

Symptoms of Rakta kshaya- It has been quoted under different context by our Acharya. Majority of these symptoms are subjective only few of them are objective.

Twak parushyam (Roughness of skin) -In Rakta kshaya skin loses its softness and becomes coarse and rough and skin looks abnormal. This may be due to Rasa kshaya and Vata vriddhi in Rakta Kshaya.Amla - Sheet Prarthana (craving for sour and cold) -This is special symptom of Rakta kshaya. There are panchet for sour 
and cold foodstuff. Dalhana clarified that the craving is due to Vata vriddhi, which render the desire for opposite taste. While desire for cold is due to diminution of Rakta which is Drava in nature. According to Chakrapani this craving is due to dual nature i.e. Agnisomiya nature of the Rakta. Rakta kshaya leads to crave for both Agni in the form of Amla Rasa and Soumya in the form of Sheet.Sira Shaithilya (loss of normal tone of Sira) Sira carries Rakta and Rakta vahana make its normal tone. However, in case of Rakta kshaya Rakta is diminished, so Sira appears very feeble which can be considering as Sirashathilya. Agnimndhya - Acharya Susrut clearly specifies Agnimndhya in Rakta kshaya in context of Arsha. Heena Varna (loss of natural complexion and luster) - Varna Pasadena is one of the important karma of Rakta Dhatu. In case of Rakta kshaya, this karma of Rakta Dhatu hampered .The Rugna complaint of the loss of natural complexion i.e. appears pale, which is prominent in palpabral conjunctiva and nails.Agni Mahabhoota is responsible for Varna or complexion. Rakta has Agneya Swabhav and thus; diminution Varna is an important manifestation of Rakta kshaya. Along with above symptoms some other associated symptoms are also seen in Rakta kshaya like-Heena Bala, Bhrama, Swashkastata, Hridaya Spandanadhikya , Tamodarshana, khalitya.

According to Ayurveda all the dravyas are Panchabhautic and thus no Dravya is without medicinal property. Dravyas are tool for physician (karnam punarbheshagam ch.vi.8/87.Thus, every Dravya is Aushadhi but every Dravya can't be used anywhere. The use of particular Dravya for particular purpose demands Yukti. Body is best physician of itself; ever second it tries to compensate every abnormal condition from with it suffer. In some deficiency disease, he craves for particular type of foodstuff to fulfill that deficient stage. Regarding this fact Acharya Susrut quoted one principle in Sutrasthana. Means in kshaya stage, body crave for particular Aahara if we fulfill that demand of body than the conditions of kshaya get resolved and Dhatu comes in stage equilibrium. The Herb Aamalki is selected to assess its effect on Rakta Dhatu in patients of Rakta kshaya, those has craving for Amla and sheet. Patients of Rakta kshaya crave for Amla and sheet Dravya. Amalaki is easily available, cheap so people of lower economic condition can afford it, has long lasting potency, durability and has very good Rasayana affect that why it is selected for study.

\section{PROPERTIES \& ACTIONS}

Rasa -Kasaya, Katu, Tikta, Amla, Swvadu .Guna (Quality): Saram, Laghu,Mrudu .Veerya (Potency): Himam, Sisiram, Himam ,Vipaaka (post digestive effect): Madhuram Karma (action): Vrsyam, Rasayanam ,Vrsyam, Bhedanam, Ruchyam ,Vrsyam, Rasayanam Rasayanam Dosha-Karma -Tridosahrt ,Pittaghna ,Kaphapitta hara, Tridosa jit .

Amalaki pacifies Vata due to the Amla taste Pitta due to Madhura and Sheet and Kapha by Ruksa and Kasayatwa. The fruit of Aamalki is Katu, Madhura, Kashaya, Amla, Atisita, Kaphaghna, Rucikara, Pittasara tapahara, It removes Srama, Vamana, Vibandha, Adhmana, Vistamba and it is like nectar. Chemical composition of fruit has Ascorbic acid, Gibberellins -A3, A4, A9.Sugars, Kaempferol, Phyllimbic acid (6.3\%), Alkaloids - Phyllantidine and Phyllantine (Zealin and derive.)Aamalki Fruit is rich in vitamin $\mathrm{C}$, Tannin, Gallic acid 5\% and Emblicol. Vitamin C is essential for synthesis and absorption of iron.

\section{Material and method}

Patients of Rakta kshaya attending the O.P.D. and I.P.D. Of Ayurvedic College Hospital fulfilling the criteria were selected for study. Research Proforma was prepared for the research work mainly on Ayurvedic guidelines.

\section{Criteria of selection}

- Age group 16 to 45 years old.

- Patients were selected irrespective of sex and socio-economic condition

- Patients having the symptoms of Rakta-Kshaya as per the Ayurvedic Classics (Su.su.15/9 \& others) have been selected.

- Patients having hemoglobin per - cent greater than 6 grams were selected.

- Patients willing to participate in study.

\section{Criteria of exclusion}

- Person having any apparent disease or involvement of any other systemic complication. 
Vyas Deepak M. , International Journal of Ayurvedic \& Herbal Medicine 8(3) May.-June. 2018 (3245-3252)

- Person having hemoglobin less than 6 and greater than 12 gm. Percent.

- Patients taking treatment for Anemia

- Pregnant and Lactating women

Plan of Wok - 76 patients were screened for study to find out their Amla Rasa and sheet Prarthana.Out of them 30 patients selected randomly for clinical study. They were randomly divided into two equal groups

- Group A :- Amla sheet Dravya (Aamalki) along with routine normal diet

- Group B :- Only on routine normal diet

The details are as below:

\begin{tabular}{|l|l|l|}
\hline Detail & Group A & Group B \\
\hline Dravya & Amla sheet $\left(\right.$ Amalki $\left.^{\#}\right)$ & - \\
\hline Aahara & Routine normal diet & Only on routine normal diet \\
\hline Matra & Five grams & - \\
\hline Anupana & Sheetal Jala & - \\
\hline kala & Prath ratrow & Prath ratrow \\
\hline Duration & 30 days & 30 days \\
\hline Patient & 15 & 15 \\
\hline
\end{tabular}

\# - Amalki Churna was self-prepaired in the Rasashastra Dept. Of Ayurvedic college.

Extent of Amla Prarthana, Sheet Prarthana, Hemoglobin percentage and RBCs count were repeated before and after 30days in both the groups.

\section{Criteria for assessment}

$>$ The Extent of Amla sheet Prarthana in Rakta kshaya Patients was assessed with the help of Labeled affective magnitude scale (LAM).

\section{Objective criteria}

$>\mathrm{Hb}$ percentage

$>\mathrm{RBC}$ count

(\# - All Hematological investigation were done on three step Hemoanalyser of Ayurvedic college Hospital

\section{Observations}

The clinical study was stared with 30 Rakta kshaya patients having Amla sheet Prarthana. Out of total 30 patients, two patients left against medical advice. Therefore, the clinical study completed on total 28 patients.

Table 1. Showing Age Wise Distribution of 28 Patients of Rakta Kshaya

\begin{tabular}{|c|c|c|c|c|c|c|c|}
\hline \multirow[t]{2}{*}{ S. No. } & \multirow{2}{*}{$\begin{array}{c}\text { Age } \\
\text { (In years) }\end{array}$} & \multicolumn{2}{|c|}{ Group A } & \multicolumn{2}{|c|}{ Group B } & \multirow[t]{2}{*}{ Total } & \multirow[t]{2}{*}{$\%$} \\
\hline & & Frequency & Percent & Frequency & percent & & \\
\hline 1 & $16-20$ & 01 & $06.67 \%$ & 02 & $15.38 \%$ & 03 & $10.71 \%$ \\
\hline 2 & $20-24$ & 11 & $73.33 \%$ & 07 & $53.85 \%$ & 18 & $64.28 \%$ \\
\hline 3 & $24-28$ & 02 & $13.33 \%$ & 03 & $23.07 \%$ & 05 & $17.87 \%$ \\
\hline 4 & $28-32$ & - & - & - & - & - & - \\
\hline 5 & $32-36$ & 01 & $06.67 \%$ & - & - & 01 & $03.57 \%$ \\
\hline 6 & $36-40$ & - & - & 01 & $07.69 \%$ & 01 & $03.57 \%$ \\
\hline 7 & $40-44$ & - & - & - & - & - & - \\
\hline & Total & 15 & $100.0 \%$ & 13 & $100.0 \%$ & 28 & $100.0 \%$ \\
\hline
\end{tabular}


Vyas Deepak M. , International Journal of Ayurvedic \& Herbal Medicine 8(3) May.-June. 2018 (3245-3252)

Table 2. Showing Extent of Amla Prarthana Wise Distribution Of 28 Pts. Of Rakta Kshaya

\begin{tabular}{|c|c|c|c|c|c|c|c|}
\hline \multirow[t]{2}{*}{ S. No } & \multirow{2}{*}{$\begin{array}{c}\text { Amla } \\
\text { Prarthana }\end{array}$} & \multicolumn{2}{|c|}{ Group A } & \multicolumn{2}{|c|}{ Group B } & \multirow[t]{2}{*}{ Total } & \multirow[t]{2}{*}{ Percent } \\
\hline & & Frequency & Percent & Frequency & Percent & & \\
\hline 1 & 1 & 1 & $6.7 \%$ & 2 & $15.4 \%$ & 03 & $10.72 \%$ \\
\hline 2 & 2 & 4 & $26.7 \%$ & 3 & $23.1 \%$ & 07 & $25.00 \%$ \\
\hline 3 & 3 & 7 & $46.7 \%$ & 5 & $38.5 \%$ & 12 & $42.86 \%$ \\
\hline 4 & 4 & 3 & $20.0 \%$ & 2 & $15.4 \%$ & 05 & $17.85 \%$ \\
\hline 5 & 5 & - & - & 1 & $7.7 \%$ & 01 & $03.57 \%$ \\
\hline & Total & 15 & $100.0 \%$ & 13 & $100.0 \%$ & 28 & $100.0 \%$ \\
\hline
\end{tabular}

The Table No 2 shows that, In Group A 46.7\% patients like Amla rasa very much, $26.7 \%$ like extremely, $20 \%$ like moderately and only $6.7 \%$ patients like Amla rasa up to greatest imaginable. On other side in Group B $38.5 \%$ patients like very much, $23.1 \%$ like extremely, $15.4 \%$ like up to greatest imaginable, only $7.7 \%$ patients like Amla rasa slightly

Table 3. Showing Extent of Sheet Prarthana Wise Distribution Of 28 Patients Of Rakta Kshay

\begin{tabular}{|l|l|l|l|l|l|l|l|l|}
\hline S.No & $\begin{array}{l}\text { Sheet } \\
\text { prarthana }\end{array}$ & Group A & \multicolumn{3}{|l|}{ Group B } & Total & Percent \\
\cline { 3 - 7 } & Frequency & Percent & Frequency & Percent & & \\
\hline $\mathbf{1}$ & $\mathbf{1}$ & 2 & $13.3 \%$ & 1 & $7.7 \%$ & 3 & $10.72 \%$ \\
\hline $\mathbf{2}$ & $\mathbf{2}$ & 2 & $13.3 \%$ & 5 & $38.5 \%$ & 7 & $25.00 \%$ \\
\hline $\mathbf{3}$ & $\mathbf{3}$ & 5 & $33.3 \%$ & 3 & $23.1 \%$ & 8 & $28.57 \%$ \\
\hline $\mathbf{4}$ & $\mathbf{4}$ & 5 & $33.3 \%$ & 3 & $23.1 \%$ & 8 & $28.57 \%$ \\
\hline $\mathbf{5}$ & $\mathbf{5}$ & 1 & $06.7 \%$ & 1 & $7.7 \%$ & 2 & $07.14 \%$ \\
\hline & Total & 15 & $100.0 \%$ & 13 & $100.0 \%$ & 28 & $100.0 \%$ \\
\hline
\end{tabular}

It is clear from the above Table3 that in Group A 33.3\% patients like cold food very much, 33.3\% like moderately $13.3 \%$ like extremely, $13.3 \%$ like up to greatest imaginable and only $6.7 \%$ patients like slightly. On other side in Group B 38.5\% patients like extremely ,23.1\% like very much , $23.1 \%$ like moderately 7.7\% like up to greatest imaginable and similarly and $7.7 \%$ patients like cold food slightly

Table 4.Showing Hemoglobin \% Wise Distribution Of 28 Pts. Of Rakta Kshay

\begin{tabular}{|c|c|c|c|c|c|c|c|}
\hline \multirow{2}{*}{ S. No } & $\begin{array}{c}\text { Hemoglobin } \\
\text { gm\% }\end{array}$ & \multicolumn{2}{|c|}{ Group A } & \multicolumn{2}{|c|}{ Group B } & Total & \% \\
\cline { 5 - 9 } & Frequency & Percent & Frequency & percent & & \\
\hline $\mathbf{1}$ & $\mathbf{0 6}-\mathbf{0 8}$ & 02 & $13.33 \%$ & - & - & 02 & $07.14 \%$ \\
\hline $\mathbf{2}$ & $\mathbf{0 8}-\mathbf{1 0}$ & 05 & $33.33 \%$ & 03 & $23.08 \%$ & 08 & $28.58 \%$ \\
\hline $\mathbf{3}$ & $\mathbf{1 0}-\mathbf{1 2}$ & 08 & $53.34 \%$ & 10 & $76.92 \%$ & 18 & $64.28 \%$ \\
\hline & Total & 15 & $100.0 \%$ & 13 & $100.0 \%$ & 28 & $100.0 \%$ \\
\hline
\end{tabular}

The Table 4 shows that ,In Group A maximum 53.34\% patients were found with Hemoglobin percent in between $10-12$ gm $\%, 33.33 \%$ in between $8-10$ gm\% and only $13.33 \%$ in between $6-10$ gm\% .On other side in Group B maximum i.e. $76.92 \%$ patients were in between $10-12$ gm\%, $23.08 \%$ in between $8-10$ gm\%..In Group B, there was no patient in between 6-8 gm\% 
Table 5. Showing RBC count Wise Distribution Of 28 Pts. Of Rakta Kshaya

\begin{tabular}{|c|c|c|c|c|c|c|c|}
\hline \multirow[t]{2}{*}{ S. No } & \multirow{2}{*}{$\begin{array}{c}\text { Red cell } \\
\text { Milli/cumm }\end{array}$} & \multicolumn{2}{|c|}{ Group A } & \multicolumn{2}{|c|}{ Group B } & \multirow[t]{2}{*}{ Total } & \multirow[t]{2}{*}{$\%$} \\
\hline & & Frequency & Percent & Frequency & percent & & \\
\hline 1 & Less than 3.5 & 07 & $46.67 \%$ & 04 & $30.77 \%$ & 11 & $39.28 \%$ \\
\hline 2 & $3.5-04$ & 07 & $46.67 \%$ & 08 & $61.54 \%$ & 15 & $53.57 \%$ \\
\hline 3 & $04-4.5$ & 01 & $06.76 \%$ & 01 & $07.69 \%$ & 02 & $07.14 \%$ \\
\hline 4 & Greater than 4.5 & - & - & - & - & - & - \\
\hline & Total & 15 & $100.0 \%$ & 13 & $100.0 \%$ & 28 & $100.0 \%$ \\
\hline
\end{tabular}

It is clear from Table 9 that in Group A $46.67 \%$ patients were found with RBCs count less than $3.5 \mathrm{milli} / \mathrm{cumm}, 46.67 \%$ in between $3.5-4.0 \mathrm{milli} / \mathrm{cumm}$ and only $6.76 \%$ in between $04-4.5 \mathrm{milli} / \mathrm{cumm}$. In Group B 61.54\% were found with RBC in between $3.5-4.0 \mathrm{milli} /$ cumm, $30.77 \%$ with less than $3.5 \mathrm{milli} /$ cumm and $7.69 \%$ in between $04-4.5 \mathrm{milli} /$ cumm. In both the Groups there was not a single patient with RBCs count greater than $4.5 \mathrm{milli} / \mathrm{cumm}$.

Table 6. Showing Effect of Aamalki Churna on Amla - Sheet Prarthana

\begin{tabular}{|c|c|c|c|c|c|c|}
\hline \multirow{2}{*}{ S. No } & $\begin{array}{c}\text { Effect of } \\
\text { Aamalki }\end{array}$ & \multicolumn{2}{|c|}{ Mean \pm SD } & df & Wilcoxon T & Critical T \\
\cline { 3 - 5 } & \multicolumn{2}{|c|}{ BT } & AT & & \\
\hline $\mathbf{1}$ & $\begin{array}{c}\text { Amla } \\
\text { Prarthana }\end{array}$ & $2.80 \pm 0.862$ & $3.33 \pm 1.047$ & 14 & 08.0 & 21 \\
\hline $\mathbf{2}$ & $\begin{array}{c}\text { Sheet } \\
\text { Prarthana }\end{array}$ & $3.07 \pm 1.163$ & $3.27 \pm 1.39$ & 14 & 13.5 & 21 \\
\hline
\end{tabular}

The Table6 shows statistical analysis of Amla sheet Prarthana of Group A. By using Wilcoxon Matched Paired Test it was found that there is significant difference (Wilcoxon $\mathrm{T}$ value is less than Critical $\mathrm{T}$ value) in the before and after observation of Amla and Sheet Prarthana of Group A.

\section{DISCUSSION}

Initially clinical study was started with 30 patients of Rakta kshaya, who having Amla sheet Prarthana .They were divided in to two groups i.e. Group A and Group B. Each contains fifteen patients but at the end of study in Group B, two patients were leave against medical advice. The patients of Group A were put on Aamalki Churna along with routine normal diet. Group B patients were put on only routine normal diet .The Extent of Amla sheet Prarthana and hematological parameters like $\mathrm{Hb} \%$ and Red cell count were observed with the help of three step Hemo - autoanalyser before and after 30days. In both the groups maximum patients were belonging to $20-24$ years age. Ayurveda accepts middle age as the Pitta dominant age. Its aggravation is responsible for catabolism and may leads to increased prevalence of Dhatu Kshaya. Maximum percentage of patients were female, It shows that females are more susceptible for Rakta kshaya. This may be due to in India maximum malnourished are females. Maximum percentage of patients were Vegetarians and they are at an additional disadvantage because certain foodstuffs that include phytates and phosphates reduce iron absorption by about 50\%. Panduta found in $78.57 \%$ patients of Rakta kshaya. The probable cause behind this be - Twacha Varna Pasadana is one of the important function of Rakta and when Rakta Dhatu gets deminuted it's function also get hampered. Other reason behind this may be due to Rakta kshaya pitta Dosha also deminuted (Due to Ashraya - Asharayi Bhave Sambandha). Bhrajaka Pitta is a type of Pitta, which is responsible for coloration of skin Therefore in Rakta kshaya panduta lakshana, is present. $46.43 \%$ Twacha parushyam lakshana was present in maximum patients. Sira shithilya present in 
Vyas Deepak M. , International Journal of Ayurvedic \& Herbal Medicine 8(3) May.-June. 2018 (3245-3252)

$17.86 \%$ of patients. Sira purana is one of the function of the Rakta Dhatu. when Rakta Dhatu gets deminuted this function also gets affected. Agnimndhya lakshana was present in $53.57 \%$ of patients. The reason behind this may be well understood by Ashraya - Asharayi Bhave Sambandha of Rakta and Pitta. Heena Bala Lakshana was present in $78.57 \%$ of patients. This may be due to the fact that Bala is an important function of Blood affected in Rakta kshaya.

In study, it observed that the maximum patients i.e. $64.28 \%$ have $\mathrm{Hb}$ ranging between $10-12$ grams percent the blood. The Hemoglobin is the pigment responsible for the red color of the Blood. The normal value of the Hemoglobin ranges between the $12-16$ grams. Thus, the patients of Rakta Kshaya show the diminished Hemoglobin percentage. The normal values of the Total Red blood cells are $3.5-5.0 \mathrm{milli} / \mathrm{cumm}$. The observations confirm that the maximum number of the Patients has the RBCs count in between $3.5-4$ milli/cumm that comes under normal range.Labeled affective magnitude scale (LAM) used in the assessment of extent of Amla Prarthana .Out of total Rakta kshaya patients ,maximum i.e. $42.86 \%$ has very much craving for Amla Rasa and Same strategy used for cold food. In study out of total patients 28.57\% like cold, foods moderately, 28.57\%like very much,

The study in Group A showed that out of fifteen patients Amla Prarthana reduced in $53.34 \%$ and it remains constant in $46.66 \%$. The overall statistical analysis with the help of Wilcoxan matched paired test or signed rank test shows that there is significant change in before and after observation of Amla Prarthana in Group A. The study in Group B shows that out of thirteen patients of Rakta kshaya. Amla Prarthana was reduced in $15.38 \%$ and it remains constant in $84.62 \%$. The overall statistical analysis with the help of Wilcoxan matched paired test or signed rank test shows that there is significant change in before and after observation of Amla Prarthana in Group B.In Group A Sheet Prarthana reduced in 33.34\% of patients, increases in $20 \%$ and it remains constant in $46.66 \%$ patients .The overall statistical analysis with the help of Wilcoxan matched paired test or signed rank test shows that there is significant change in sheet Prarthana before and after observation. In Group B Sheet Prarthana was reduced in $15.38 \%$ of patients, it increases $15.38 \%$ and it remains constant in $69.24 \%$ patients. The overall statistical analysis with the help of Wilcoxan matched paired test or signed rank test shows that there is insignificant change in sheet Prarthana before and after observation.

In Group A Hemoglobin percentage increased in $73.34 \%$ of patients; it decreases in $13.33 \%$ and remains constant in $13.33 \%$. The over all statistical analysis with the help of student's paired't' test shows significant effect of Aamalki Churna along with routine normal diet on Hemoglobin percentage of Rakta kshaya patients. ( $\mathrm{P}<0.05$ i.e. 0.023) . - In Group B Hemoglobin percentage increased in $46.15 \%$ of patients, it decreases in $46.15 \%$ and remains constant in $7.70 \%$. The over all statistical analysis with the help of student's paired ' $t$ ' test shows insignificant effect of routine diet on Hemoglobin percentage of Rakta kshaya patients. ( $\mathrm{P}>0.05$ i.e. 0.55).In Group A red cell count was increased in $80 \%$ of patients and deceases slightly in $26.66 \%$, .The overall statistical analysis with the help of student's paired' $t$ ' test shows significant effect of Aamalki Churna on RBCS count of Rakta kshaya patients. (P < 0.05 i.e. 0.01). - In Group B Red cell count was increased in $53.85 \%$ of patients and deceases in $38.46 \%$.The over all statistical analysis shows with the help of student's paired't' test insignificant effect of routine diet on RBCs count of Rakta kshaya patients. $(\mathrm{P}>0.05$ i.e. 0.35$)$

\section{RESULTS AND CONCLUSION}

In Group A After giving Amla, sheet Dravya Aamalki Churna to the patients of Rakta kshaya having AmlaSheet Prarthana, Significant changes were seen in Amla - Sheet Prarthana. Hemoglobin percentage $(\mathrm{P}<$ 0.05 i.e. 0.023$)$ and Red cell count $(\mathrm{P}<0.05$ i.e. 0.015$)$. In Group B patients of Rakta kshaya was on routine normal diet. It was observed that Amla Prarthana was significantly reduced but changes observed in sheet Prarthana was insignificant. There is an insignificant changes observed in Hemoglobin percentage ( $\mathrm{p}>0.05$ i.e. 0.57) and RBC (P > 0.05 i.e. 0.35). It is concluded that Amla Sheet Dravya Amalaki has significant effect to reduce Amla Sheet Prathana and to increase Haemoglobin,RBC count.

\section{BIBLIOGRAPHY}

1. Shushrut. Sushrut Samhita. In Shashtri A. Doshadhatumalakhyayavriddhivigyaniya. Varanasi; 2005. p. 56. 
Vyas Deepak M. , International Journal of Ayurvedic \& Herbal Medicine 8(3) May.-June. 2018 (3245-3252)

2. Agnivesh, Drudhabala, Charak. Charak Samhita. In Tripathy B. Sutrastana, Vidhishonotadhyaua. Varanasi: Chaukhambha Surbharati Prakashan; 2005. p. 429.

3. Shushrut. Shushrut Samhita. In Shashtri A. Sutrastana,Shonitvarnaniyaadhyaya. Varanasi: Chaukhamba Sanskrit Sanstan; 2005. p. 56.

4. Sushruta. Sushrut Samhita. In Shashtri A. Sutrastana,Vranaprashnaadhyaya. Varanasi: Chaukhamba Sanskrit Sanstana; 2005. p. 85.

5. Sushruta. Sushruta Samhita. In Shashtri A. Sutrastana, Doshadhatumalkshayavriddhivigyaniya adhyaya. varanasi: Chaukhamba Sanskrtit Sanstana; 2005. p. 56.

6. Agnivesh, Charak, Drudhabala. Charak Samhita. In Tripathy B. Chikitasastan,Raktapittadhyaya. Varanasi: Chaukhamba Sanskrit Acadamy; 2006.

7. Shushruta. Shushrut Samhita. In Shashtri A. Sutrastana, Doshadhatumalvriddhivigyaniya. Varanasi: Chaukhamba Sanskrit Sanstan; 2005. p. 58.

8. Vagbhata. Ashtang Hrudaya. In Paradkar SS. Sutrastana, Doshadivigyaniya. Varanasi: Chaukhamba Surbharati Prakashan; 2002. p. 185.

9. Vagbhata. Ashtang Samgraha. In Murthy KRS. Sutastana, Doshadivigyaniya. Varanasi: Chaukhamba Orientalia; 2000. p. 353.

10. Vyas DM, Umarkar SV. observational study of Amla sheet food craving in Anaemic patients. International journal of Ayurvedic and Herbal Medicine. 2018 March April; 8(2). 